\title{
The Development of Learning Strategies in Pesantren Studies on the Transformation of the Teaching System in Pesantren
}

\begin{tabular}{|c|c|}
\hline \multicolumn{2}{|r|}{$\begin{array}{c}\text { Muh. Mustakim } \\
\text { Alma Ata University Yogyakarta, Indonesia }\end{array}$} \\
\hline (A) Check for updates open 0 access (c) (i) (2) & DOI : https://doi.org/10.46245/ijorer.v2i2.94 \\
\hline Sections Info & \multirow{13}{*}{$\begin{array}{l}\text { The fundamental question of the research is how the learning strategies are } \\
\text { developed in pesantren. follow the development of modern learning } \\
\text { strategies or survive with his salafiah learning system. This research uses a } \\
\text { case study. and research tends to be explanatory. Collecting data through } \\
\text { observation, interviews and documentation. The data is taken in general, } \\
\text { then sorted, selected, selected and reduced only in relation to the problems } \\
\text { of this research. To maintain the validity of the data, there were three } \\
\text { things done, namely extending the stay and interacting with respondents; } \\
\text { make observations seriously and diligently; and tested by triangulation } \\
\text { adopting the interactive model from Miles and Huberman. The findings } \\
\text { from the data obtained are compiled by categories and themes, analyzed } \\
\text { inductively conceptually and then made narrative explanations so that they } \\
\text { are arranged into certain propositions and developed into new theories } \\
\text { based on data analysis and narrative theoretical interpretation. The results } \\
\text { of this research is that pesantren develop all types of learning strategies, } \\
\text { namely direct learning strategies, learning indirect strategies, interactive } \\
\text { learning strategies, empirical learning strategies and active learning } \\
\text { strategies. This fact is reasonable because the education and learning } \\
\text { process in pesantren is } 24 \text { hours. These findings indicate that pesantren } \\
\text { accept all developments while maintaining their characteristics, so that the } \\
\text { findings of this study lead to a theory of pesantren flexibility while } \\
\text { maintaining their identity. The findings of this study can be continued in } \\
\text { research on learning in certain pesantren, because it can be different from a } \\
\text { pesantren compared to other pesantren. }\end{array}$} \\
\hline Article history: & \\
\hline Submitted: February 09, 2021 & \\
\hline Final Revised: February 16, 2021 & \\
\hline Accepted: March, 162021 & \\
\hline Published Online: March 31, 2021 & \\
\hline Keywords: & \\
\hline Education & \\
\hline Flexibility & \\
\hline Identity & \\
\hline Pesantren & \\
\hline Strategy learning & \\
\hline 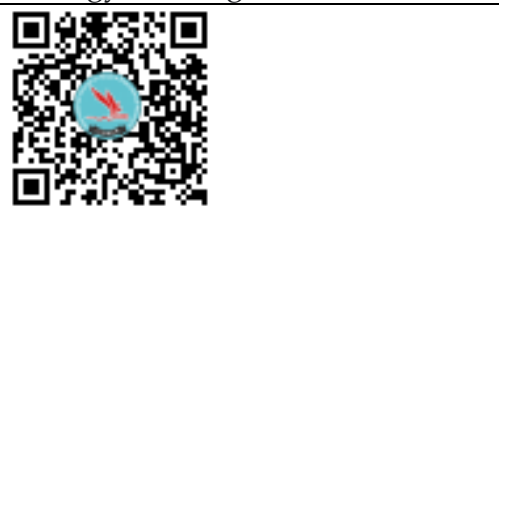 & \\
\hline
\end{tabular}

\section{INTRODUCTION}

Learning aims to make students become learning persons so that an effective teacher is when they are able to give birth to students who continue to learn. Deciding to choose a learning strategy will be good if the teacher understands the learning objectives. if a teacher knows this step, the material taught will be understandable. He will use various learning resources to motivate and increase students' interest in learning so that the learning process goes according to the learning plan. Learning strategies that deny students' learning styles will be far from the essence of education itself. The formation of a learner's attitude for students is not sudden, but through a process that sometimes takes a long time, sometimes briefly. Each individual has characteristics that ultimately have different learning styles. There are two ways the process of forming this attitude, namely habituation and modeling (Baharun et. al, 2019; Matiisen et al., 2020; Simkova, 2015).

Hamruni said that forming attitudes through habituation can adopt Skinner's operant conditioning theory. This theory emphasizes the process of affirming the child's response. When a child with achievement is given reinforcement by giving gifts or fun behavior such as praise, the child will increasingly try to improve his positive attitude. 
The Development of Learning Strategies in Pesantren Studies on the Transformation of the Teaching System in Pesantren

While the modeling process was initially carried out by giving examples or ordering children to do something, then they were given an understanding of why they needed to do this (Hamruni, 2016; Nisbet et. el, 2017; McLeod, 2018).

Deciding to choose a learning strategy must consider learning objectives, materials and subject matter, effective in selecting learning strategies (whether one or more strategies is sufficient). besides that, it is necessary to consider the student's condition such as student maturity, talent, interest, condition and learning style. Other considerations are the learning components, namely teachers, students, learning objectives, learning materials, learning activities, methods, learning tools, learning resources, evaluation of learning and learning situations or environments Hamruni, 2016; Sumantri, 2015).

The development of learning strategies in this study aims to develop learning strategies that are structured logically and systematically to be developed in learning planning to be more effective, efficient and to optimize existing resources to achieve learning objectives. Learning strategies also need to consider negative tendencies and personal conditions of students, from early on to plan evaluation and follow-up plans for learning outcomes with the main focus on efforts to overcome learning difficulties, learning conditions and the consequences of the results of the evaluation of learning evaluation ( Suhana, 2014; Hamruni, 2016;).

The importance of this learning strategy also applies in pesantren. Pesantren is the oldest islamic educational institution in indonesia. The purpose of boarding school education is to form a taqwa personality and tafaqquh fiddin namely printing Islamic religious experts (Damanhuri et al., 2013; Fuadi et. al, 2020; Salim, 2014 Ma'arif, 2018; Royani, 2018). Pesantren (Islamic boarding schools) have long experience in educating students (students). so that pesantren has several unique learning systems that have been implemented longer than other educational institutions (Maunah, 2015; Munadi, 2016; Ritonga et al., 2019; Wajdi et. al, 2019). whether in its development the pesantren will maintain its learning system by rejecting the development of existing modern learning or replacing its learning with fully modern learning strategies.

\section{Research Aim and Research Questions}

The description above leads to a research question in this study, how the learning strategy in pesantren. In order to provide a complete picture of the learning strategy in writing, it will discuss the development of learning strategies, their implementation in pesantren to the efforts of pesantren to develop learning strategies as new findings from this study.

\section{RESEARCH METHOD}

This research is a qualitative research. The main data source was taken from the research location which was the main object of this research, namely the Pesantren Ibnu Abbas. Research is more explanatory and leads to the use of case studies as a strategy. Collecting data through observations, interviews, audio-visual materials, documents and various reports and reporting case descriptions or case themes. Qualification of the data collected focuses on answering research problems. The data is taken in general, then sorted, selected, selected and reduced only in relation to the problems of this research (Yin, 2012; Creswell, 2016; Sugiyono, 2016 ; Muhadjir, 2013). 
The Development of Learning Strategies in Pesantren Studies on the Transformation of the Teaching System in Pesantren

To maintain the validity of research data, accuracy and validity are required since the data search process. Noeng Muhadjir stated that at least three things needed to be done to protect it. first, extend stay and interaction with respondents. second, making observations seriously and diligently, and third, triangulating testing. The design of the data analysis stages in this study adopted an interactive model from Miles and Huberman or more famously with the triangulation model, namely the combination of observation and interviews. Direct observation in a focused and structured manner, structured interviews to find answers to initial hypotheses, unstructured interviews, especially interviews with leaders, teachers and students (Sugiyono, 2016; Muhadjir, 2013; Mustakim, 2019).

The analysis was carried out simultaneously between data reduction, display data, and verification. So that the data analysis is done inductively and comparatively and then the generalization value is taken. So that the data search process is not intended to test the initial hypothesis of this study, but rather is the formation of an abstraction based on the results collected, then the theory is grouped from the bottom up from several parts - the amount of data - collected and interrelated data so that it becomes clear. The findings obtained from the cases are arranged in categories and themes, analyzed inductively conceptually, then made a narrative explanation so that they are arranged into certain propositions and developed into theories. Then in the end the theory recommends compiling a systematic conception based on data analysis and theoretical interpretation that is narrative (Creswell, 2016; Sugiyono, 2017)

\section{RESULTS AND DISCUSSION}

Barbara L. Mc Combs explains that research on new learning strategies began in the last five decades, namely in the late 1960s and early 1970s when the theory of learning "started" a lot with military education and computer operation education. Research on learning strategies is a derivation of "study skills and memory skills" by Hare (1963), Atkinson and Shiffrin (1968), Hagen and Kingsley (1968), Belont and Butterfield (1969), Ausubel and Fitzgerald (1962), Ausubel and Youssef (1963) which is a continuation of research on the value and learning ability of students "theory of behaviorism" Skinner (1953). Then, in its development, this learning theory experienced an interest in being "connected" to military education as that of Neckissey (1971), Mc. Combs (1973) and Judd (1979). One part of learning development is the learning strategy (Combs, 2012; Schunk, 2012; Mc. Combs, 2017; Davis et al., 2018).

\section{Definition of learning strategies}

The strategy means a strategy or plan containing a series of activities designed to achieve certain goals. In the beginning, a strategy was used in the military world, this was intended as a way to use all military force to win a war by considering various factors both from within and outside. Arranging a strategy from the start before going to the battlefield, considering the strength of the troops they have, the number and strength of weapons, the motivation of the troops and gathering information about the opposing forces (strength, troops, weapons) to then develop tactics, tactics and warfare techniques as well as the right time to carry out attacks and others. Or in another illustration, what a football coach does, he will determine the most appropriate strategy to win a match after he understands all the potential of his team and understands the strength of the opposing team (Eggen, 2012; Sumantri, 2015). 
The Development of Learning Strategies in Pesantren Studies on the Transformation of the Teaching System in Pesantren

Learning is the equivalent of instruction which means the process of making people learn. Learning is understood as an effort to teach students to learn, there is two-way communication, namely the teacher teaching and learning students. Learning is more than just delivering subject matter, but also interpreted as a process of regulating the environment so that students learn. Learning must empower, encourage the achievement of specific competencies and behaviors so that students are able to become learners throughout their lives and be able to create a learning society. The learning strategy is a plan of action, the use of methods, and the use of various resources or strengths to achieve learning goals. The agreement that a learning strategy is a plan, method, or series of activities designed to achieve a particular education goal has been explained by many experts and researchers about learning strategies. In line with this definition, Wina Sanjaya defines a learning strategy as a plan that contains a series of activities to achieve certain educational goals. It's just that, focusing more on learning strategies is an activity at the beginning before learning, namely planning. In this case, Wina Sanjaya quoting J.R. David defines the learning strategy as a learning plan as adopted by Hamruni above (Mustakim, 2019).

Hamalik explained that learning strategies as methods and procedures adopted by students and teachers in the learning process to achieve learning objectives and emphasized the student-centered approach. This view was put forward by Crawford, Saul, Matthews, Makinster, Hisyam Zaini, Bermawie Munthe, Sekar Ayu Aryani and Mel Siberman (Nisbet et. al, 2017; Fanani, 2014; Zaini, 2016). If the learning strategy is linked with several parts of learning. then the hierarchical relationship between learning strategies, learning approaches, learning methods, learning techniques, learning tactics and learning models can be illustrated in the following chart:

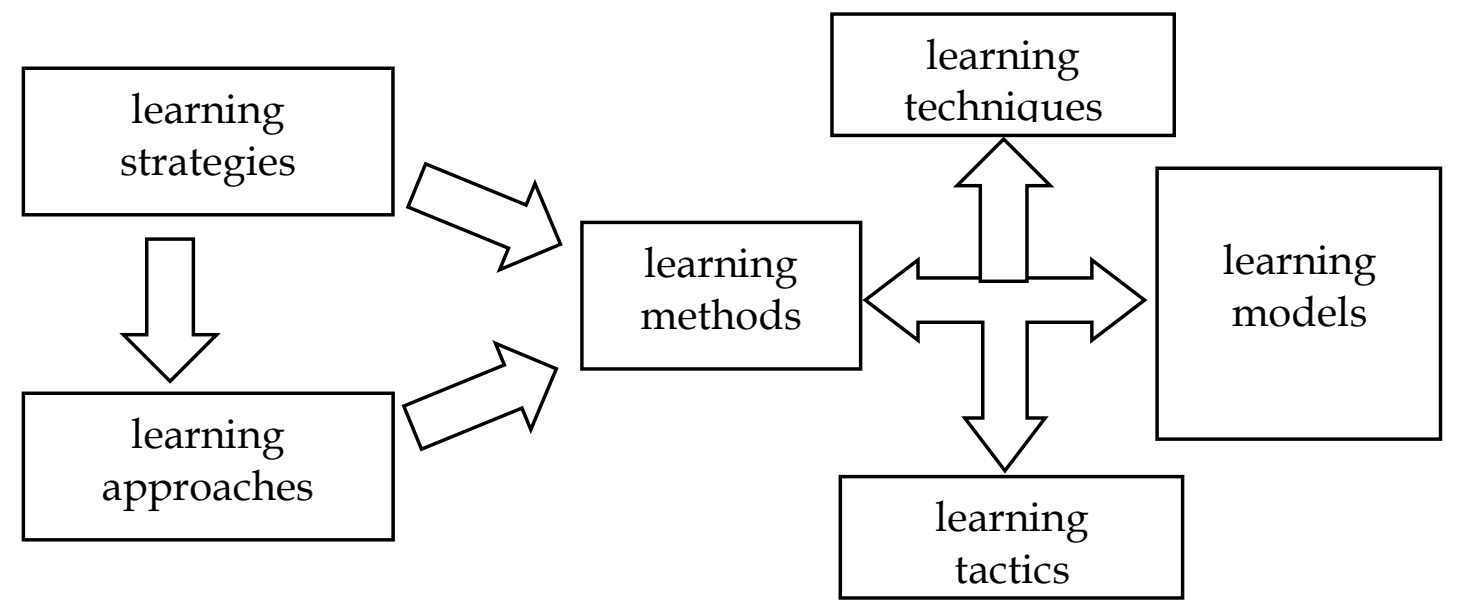

Figure 1. The relationship between learning strategies and other learning terms.

The relationship chart above shows that to achieve predetermined learning objectives, the teacher must choose to decide which learning strategy is considered the most suitable for the learning objectives. The strategy chosen depends on the approach used, then how to implement it in learning is to choose one or many learning methods that are most suitable. In carrying out the method required learning techniques that are most relevant to learning tactics which often differ from one teacher to another. So that the teacher can form a specific learning models (Riyanto, 2014; Laland et. al, 2019; Salimans et al., 2017). 
The Development of Learning Strategies in Pesantren Studies on the Transformation of the Teaching System in Pesantren

A teacher is often different from other teachers when choosing a learning method. Each teacher decides a learning strategy to achieve learning goals. In principle, the learning strategy deals with two main statements. First, the learning strategy is the process of planning learning activities, learning methods, and utilizing learning resources before learning takes place. Second, the strategy is arranged to achieve the learning objectives. The selection must be measured and formulated well before the learning process (Hamruni et.al, 2017; Sumantri, 2015; Zaini, 2016).

Sanjaya distinguishes learning strategies in terms of how they are presented and how to manage them into two types. The first is a deductive learning strategy, namely a learning strategy that is carried out by learning the concepts first and then finding conclusions and illustrations. This strategy is also called a general to specific learning strategy. Second, the inductive learning strategy, where the materials learned are started from concrete things or examples, and then students are slowly exposed to more complex and difficult material. This strategy is also called a specific to general learning strategy. Meanwhile, Rowntree classifies three learning strategies, namely (1) exposurediscovery learning, (2) group learning strategies, (3) individual learning strategies (Sanjaya, 2013; Sanjaya et al., 2013).

The learning strategy departs from the Teacher centered / conservative approach / conventional learning approach and the Student-centered / liberal approach / active student learning approach. The classification of learning strategies is (1) Direct Learning Strategies by the teacher, (2) Indirect Learning Strategies also called inquiry, inductive, problem solving, decision making, and discovery. The teacher acts as a facilitator because it is student-centered, (3) Empirical Learning Strategy (experimental), oriented to inductive activities, student-centered and activity-based, (4) Interactive Learning Strategies; emphasize more on discussion and sharing between students and teachers, (5) Independent Learning Strategy, aimed at building individual initiative, independence, and self-improvement (Hamruni et.al, 2017; Sumantri, 2015; Zaini, 2016). The detailed his strengths and weaknesses as follows:

Table 1. The strengths and weaknesses of the learning strategy.

\begin{tabular}{|c|c|}
\hline $\begin{array}{c}\text { Types of Strategy } \\
\text { Learning }\end{array}$ & Strengths and weaknesses \\
\hline $\begin{array}{l}\text { 1. Direct Learning } \\
\text { Strategies }\end{array}$ & $\begin{array}{l}\text { strengths } \\
\text { effective for specifying information or building skills step by } \\
\text { step and easy to plan and use. } \\
\text { weaknesses } \\
\text { when developing abilities, processes, attitudes, and critical } \\
\text { thinking need to be combined with other learning strategies. }\end{array}$ \\
\hline
\end{tabular}


The Development of Learning Strategies in Pesantren Studies on the Transformation of the Teaching System in Pesantren

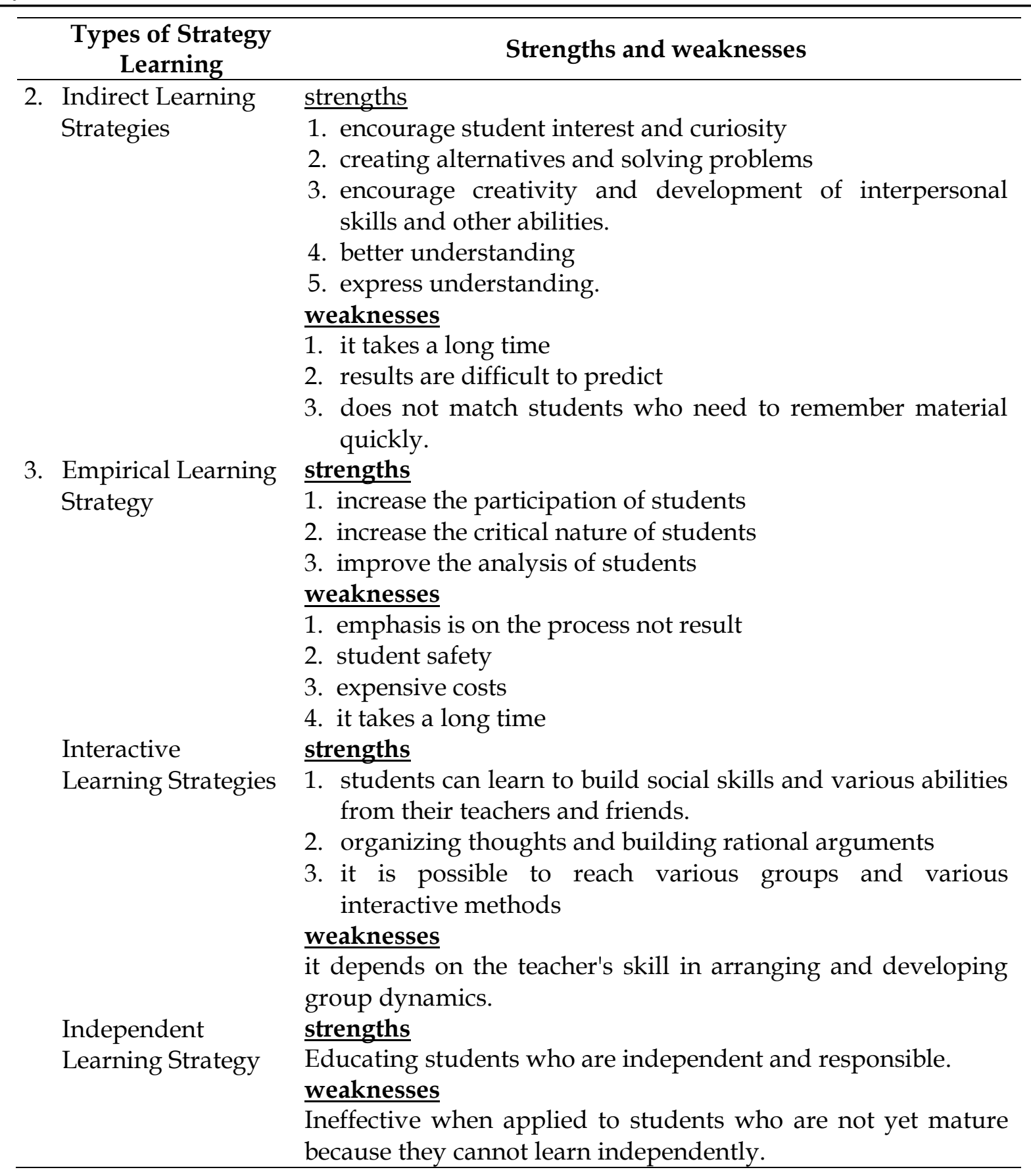

From this description, it can be understood that the learning strategy is dynamic and continues to develop. There are distinguish it from learning methods, on the other hand, not a few identify it with learning methods, even Ismail in his book PAIKEMbased Islamic Religious Learning Strategies gives a similar meaning to methods, methodologies, approaches, techniques, and learning procedures with learning strategies. While Hamruni provides a different understanding between the learning method and the learning strategy, however, as illustrated in the table above, it implies that the two are identical. In general, learning strategies can be classified based on the learning presentation process and approach. Both Hamruni, Wina Sanjaya, and others agree that the development of learning strategies departs from two learning approaches, namely student-centered or teacher-centered (Hamruni, 2016; Hamruni et. al, 2017). 
The Development of Learning Strategies in Pesantren Studies on the Transformation of the Teaching System in Pesantren

\section{Learning Strategies in Pesantren}

The learning approach at pesantren is holistic because the learning process and daily activities become one unit, become an integral part of everyday life in the pesantren. The education developed aims at preserving religion and creating value. Mastuhu said that learning at the pesantren was at least through sorogan, bandongan, halaqah and tahfidz or memorization. Sorogan comes from the Javanese word sorog which means to offer, a santri hands over his kitab kuning (yellow book) to the Kyai to ask to be taught. The learning process is carried out individually by a student reading and translating the kitab kuning to a teacher so that there is an intensive interaction to both. After the students finish reading under the guidance of the Kyai, they get a ijazah (usually given orally) and after that, they can move to another pesantren to study other kitab (books). This learning system by Sabarudin is identified with learning with individual services (individual learning process). Students must prepare themselves before learning (S.A.P. et al., 2020; Mustakim, 2019)

In succession to achieve the learning objectives, indirect learning strategies or empirical (experimental) learning strategies and interactive learning strategies can be used. These three strategies are possible in this sorogan learning system. The learning strategy is not direct because the students choose the book they want to study and then they learn to understand and analyze the sentence structure building (nahwu-sorf) to then translate it so that the students' problem-solving skills and inquiry experiences will be needed in this method. Sorogan learning can also use experimental learning strategies, where students try to understand and translate the book in it and then deposit it to the Kyai or Ustadz (teacher). The interactive learning strategy can also be considered because when depositing the selected reading and translation of the kitab kuning (yellow book), there will certainly be an interaction that can even become a discussion between the students and the teacher. Active learning methods are widely used in the Sorogan learning system. Santri are expected to be able to apply ilmu alat (tool science) such as nahwu (Arabic grammar), sharaf (morphology), and others that they have studied theoretically in pesantren so far, hence the cognitive aspect becomes dominant.

Zamakhsari Dhofier provides pre-conditions for students who have the right to follow the sorogan system, which is to have mastered the recitation of the Koran (alQur'an). Usually, students are required to be able to read the book correctly and will only move or receive new lessons if they have mastered it and have repeatedly studied the lesson before. The teacher at this level of learning emphasizes quality and He is not interested in assisting more than three or four students. In the author's opinion, this is very necessary, because how someone will read, understand and explain the kitab kuning written in Arabic if he does not have the competence to read the al-Qur'an. Moreover, the main reference in the kitab kuning which is generally written by scholars in the 12-13 century AD refers to him (Dhofier, 2014).

Another view is given by Ali Anwar, his research at Pondok Lirboyo suggests that the lessons used are bandongan, sorogan and hafalan (memorization). Until now, the sorogan al-Qur'an that still exists, is learning al-Qur'an using the sorogan system, while learning the kitab kuning (yellow book) is used in the main lodge Lirboyo for students who experience delays in understanding. This shows that the learning system in pesantren is quite dynamic in developing along with the needs of the times and of 
The Development of Learning Strategies in Pesantren Studies on the Transformation of the Teaching System in Pesantren

course the pesantren itself. However, it is a shared knowledge that the main pesantren learning system is sorogan and bandongan (Asyhar, 2016; Malisi, 2012).

Bandongan comes from the Javanese word bandong which means to go in groups. a group of students learn together to listen the explanation from the Kyai who translates sentence by sentence from the kitab (book) being studied. Learning in Pesantren - in general - examines the kitab kuning (yellow book) where the students listen to the verbal delivery by the Kyai (Ajengan, Ustadz or Tuan Guru) while the students hold the kitab while giving the vow as read by the Kyai and record the explanation, both lughawi (language) and ma'nani (meaning), but van Bruinessen's criticism is that the explanation of this kitab (book) is rarely connected with concrete things and the contemporary era (Bruinessen, 2015).

The bandongan learning system is teacher centered and deductive. As a collective service (collective learning process), the teaching method uses the lecture method where the kiai reads a part of the book in front of a large group of students (usually an advanced level) at certain times. The direct learning strategy was chosen because the understanding of this kitab continuity requires a comprehensive understanding, therefore Kyai with his scientific authority becomes the main foundation of this learning.

In its development, Van Bruinessen's criticism that the lack of contextualization of kitab (book studies) with the bandongan system seems to be refuted, where the Kyai's often relate the explanation of the books they read and explain with contemporary realities even though they depend back on Kyai's taste, competence and experience so that they differ from one another. In implementing the bandongan system the translators must master Arabic grammar, literature and other branches of science. Those who have broad khibrah and wish to contextualize will certainly have a broader description than those who tend to limit themselves to contemporary developments which are very dynamic and fast (Bruinessen, 2015).

Halaqah means circle, this is meant in learning to form a circle for discussion between participants and their companions. Halaqah discusses the teaching or translation of the contents of the book - yellow - by Kyai or ustadz about "what" is not "why" so discussing to match each other's understanding of the meaning of the translation of the contents of the book is not true or wrong. According to Zamakhsari Dhofier the halaqah system is a development of bandongan, where a group of students study under the guidance of a teacher. In general, in big pesantren there are various halaqah (bandongan class) which teach elementary books to a high level. Often Kyai ordered senior santri to teach in these halaqah. They get the title "ustadz" and later if one or two of the ustadz have become senior santri are mature experienced in teaching major books, they will get the title "young kyai" (Shiddiq, 2017; Sholihin, 2016; Soleh et al., 2018).

Learning in pesantren with the halaqah system tends to be interactive learning strategies, where interactive discussions between students under the guidance of a young ustadz make learning more memorable than students just listening. A study by Susan Kovalik and Karen Olsen in Ali Anwar states that the absorption of the learning process is $10 \%$ of what we hear, $15 \%$ of what we see, $20 \%$ of what we see and hear, $40 \%$ of what we discuss, $80 \%$ of what we experience directly and we practice and $90 \%$ of what we teach to others. Mahmud Yunus criticized the halaqah system because the 
The Development of Learning Strategies in Pesantren Studies on the Transformation of the Teaching System in Pesantren

success rate of creating the big Ulama was no more than one percent. Karel A. Steenbrink disagrees, because it is too sharp and one-sided, that is, looking at the intellectual aspect only, although Mahmud Yunus agrees to prepare religious intellectuals, it is necessary to understand that students and parents who house their children do not fully expect their children to become scholars but how to be good Muslims (Steenbrink, 2015; Mustakim, 2019; Asyhar, 2016; Nata, 2014).

Hafalan learning system termed by mastuhu with lalaran, Ali Anwar called by muhafazhah as in the Pesantren Liroboyo Kediri. Meanwhile, Sabarudin uses the term tahfidz when describing learning at the Pesantren Tarjih Muhammadiyah Yogyakarta. In principle, the learning process is relatively the same. Lalaran is an individual study in which the students memorize independently, usually anywhere such as in the mosque, near the tomb, mosque foyer, room foyer and other places (Afif, 2019; Akbar et. al, 2018; Kartika, 2019; Mustakim, 2019; Hidayah, 2019).

Although it has often been criticized, this rote learning system is still widely practiced in many Islamic boarding schools. Azyumardi Azra, for example, when interviewed by Ulil Abshar-Abdalla on the Islamic study of the utan kayu radio as quoted by Ali Anwar, argued that the emphasis on rote memorization should be avoided, but rote memorization turned out to be the main method of learning in pesantren, in Lirboyo and other pesantren, to pesantren at the rote student level as well. remains in effect. Memorization has a long history in Islamic education. Since the beginning of the emergence of Islamic memorization, it has been the main learning process in maintaining the authenticity of the Qur'an, continued with hadith more than that, the power of memorization has become the main value of one's Islamic scientific authority (Afif, 2019; Mustakim, 2019).

Except for the four learning systems (sorogan, bandongan, halaqah and memorization / lalaran) also developed musyawarah, muhadlarah and muhadatsah. Musyawarah are carried out by grouping small groups of students between three and five people discussing the kitab (books) that have been studied, usually many pesantren focus musyawarah (deliberation) on the field of fiqh. Perhaps among the fields that will become a demand in the community in religion a lot revolves around this field. Some pesantren categorize deliberations for elementary level students by discussing taqrib and bahtsul masail for the above levels usually studying al-Mahalli, Fathul Qarib and Taqrib such as learning activities at the Pesantren Lirboyo (Afif, 2019; Mustakim, 2019).

Muhadatsah comes from the Arabic hadatsa which means conversation, dialogue or speaking. Learning means conversation or dialogue between students using Arabic with the aim of providing Arabic linguistic competence, especially speaking in Arabic and being accustomed to speaking it. Muhadatsah is mostly done in Pesantren that have a tendency towards active language such as the Gontor pesantren and other modern Islamic boarding schools. While the muhadlarah system is student-based learning with independent learning strategies, where students practice lectures, learn to speak in public (other students). Public speaking learning has been developed in various Islamic boarding schools, especially in modern pesantren such as Gontor, which has become the main individual capacity building program for santri (Akbar et. al, 2018; Mustakim, 2019; Badriah, 2016). 
The Development of Learning Strategies in Pesantren Studies on the Transformation of the Teaching System in Pesantren

Learning methods at the Pesantren Tarjih Muhammadiyah using such as lectures, tadris wa ta'lim, assignments, simulations, practices (demonstrations), discussions and muhadlarah 'ammah or stadium general. In terms of the learning approach, the learning system is included in the Teacher centered approach is bandongan while others are identical to Student centered namely sorogan, lalaran / memorization, deliberation, muhadlarah and muhadatsah, while halaqah is a combination of the two (Mustakim, 2019; Badriah, 2016).

Pesantren develop all types of learning strategies, namely direct learning strategies, indirect learning strategies, interactive learning strategies, empirical learning strategies and active learning strategies. This fact is reasonable because the education and learning process in pesantren is 24 hours. These findings indicate that pesantren accept all developments while maintaining their characteristics, so that the findings of this study lead to a theory of pesantren flexibility while maintaining their identity.

The development of learning strategies at Pesantren Ibnu Abbas consists of Tadabbur using direct learning strategies because it is a direct assessment process by the director (Kyai) of the pesantren or by muhafiz in their respective halaqahs. Direct learning strategies are also used in the learning process of tahsin fardi, which is a form of individual service provided to students, especially those who have below average reading / recitation quality. Ziyadah and muraja'ah indirect learning strategies. Ziyadah is a process of depositing the memorization that has been prepared beforehand in the isti'dad process to the muhafiz so that the learning process is identical to the sorogan in the traditional pesantren. Muraja'ah is a learning process by repeating the memorization of the Qur'an that is already owned. The learning strategy can be categorized into indirect learning strategies, especially qiraatu tilmidz 'ala al muhafiz, al-muraja'ah' abra imtihan, al-muraja'ah 'abra al-musabaqah when students read in front of Muhafiz several verses (maqtha' / maqra') which has been memorized.

Interactive learning strategies are used in learning halaqah Qur'an and tahsin fardi and tahsin mujawad. In the halaqah, there is an interaction between Muhafiz and students related to memorization, discussing various things about the recitation of the Qur'an, either to increase memorization or maintain memorization.

The development of independent learning strategies is used in the recitation and isti'dad processes. Both of these learning processes provide the widest opportunity for students to develop and prepare memorization before being deposited by Muhafiz. Independent learning strategies are also used in muraja'ah learning with the al-muraja'ah fi as sholah method, al-muraja'ah al juziyyah, al-muraja'ah abra al-'iqab, al-muraja'ah 'abra haflah khatmil Qur. 'an, al-muraja'ah al Jama'iyyah, al-Qiraah and qiraatu Muhafiz' ala tilmidz. Learning and coaching by "kesantrian" who takes care of the students uses more independent learning strategies. Various activities are carried out independently by students managed by OSIA or the students organization of Pesantren Ibnu Abbas. These various activities such as muhadatsah, night study, muhadlarah and other religious activities except halaqah tarbawiyah tend to develop interactive learning strategies

\section{CONCLUSIONS}

Pesantren uses various learning strategies, although definitively does not mention the classification, the results of the identification of the authors show that all learning strategies are used in the pesantren. Teacher-centered direct learning strategies are used 
The Development of Learning Strategies in Pesantren Studies on the Transformation of the Teaching System in Pesantren

in the bandongan learning system. Indirect learning strategies that provide more opportunities for students (students) or student centers are developed in the sorogan learning system because before going to the teacher to read "interpreting" the kitab kuning (yellow book) of course, must have careful preparation for the material to be deposited. So that the sorogan system also uses empirical learning strategies and interactive learning strategies. Interactive learning strategies that tend to be student centered and teacher centered are used in the learning systems of halaqah, musyawarah (deliberation), muhadlarah, muhadatsah and sorogan. Empirical learning strategies are used in the sorogan learning system. Meanwhile, independent learning strategies are more widely used in lalaran / memorization, musyawarah / deliberation, muhadlarah and muhadatsah learning systems. Pesantren Ibnu Abbas develop the direct learning strategies are used in tadabbur learning system, and tahsin fardi learning system. Indirect learning strategies are used in ziyadah and muraja'ah learning system. The indirect learning strategies are used in qiraatu tilmidz 'ala al muhafiz, al-muraja'ah' abra imtihan, almuraja'ah 'abra al-musabaqah system. Interactive learning strategies are used in learning halaqah Qur'an and tahsin fardi and tahsin mujawad. The development of independent learning strategies is used in the recitation and isti'dad processes. The last, the independent learning strategies are used in muhadatsah, night study and muhadlarah.

\section{REFERENCES}

Afif, M. (2019). Penerapan metode sorogan dalam meningkatkan baca kitab di pondok pesantren Tarbiyatun Nasyi'in. KABILAH: Journal of Social Community. https://doi.org/10.35127/kbl.v4i2.3592

Akbar, A., \& Ismail, H. (2018). Metode pembelajaran kitab kuning di pondok pesantren Daarun Nahdhah Thawalib Bangkinang. Al-Fikra: Jurnal Ilmiah Keislaman. https://doi.org/10.24014/af.v17i1.5139

Anwar, A. (2011). Pembaruan Pendidikan di pesantren lirboyo kediri. Pustaka Pelajar.

Asyhar, A. (2016). Model transformasi pendidikan pondok pesantren di pulau Bawean Gresik. JOIES : Journal of Islamic Education Studies, 1(2), 277-302.

Baharun, H., \& Adhimiy, S. (2019). Learning innovation in pesantren: The Strategy of stifin method for enhancing children's intelligence potential. TARBIYA: Journal of Education in Muslim Society. https:/ / doi.org/10.15408/tjems.v6i2.9247

Bruinessen, M. Van. (2015). Kitab kuning, pesantren dan tarekat. In Yogyakarta, Gading Publising.

Combs, B. (2012). Assessing and addressing literacy needs: Cases and instructional strategies. In Assessing and Addressing Literacy Needs: Cases and Instructional Strategies. https://doi.org/10.4135/9781452243900

Creswell, J. W. (2016). Research Design pendekatan metode kualitatif, kuantitatif, dan campuran. Pustaka Pelajar.

Damanhuri, A., Mujahidin, E., \& Hafidhuddin, D. (2013). Inovasi Pengelolaan pesantren dalam menghadapi persaingan di era globalisasi. Ta'dibuna: Jurnal Pendidikan Islam. https://doi.org/10.32832/tadibuna.v2i1.547

Davis, D., Chen, G., Hauff, C., \& Houben, G. J. (2018). Activating learning at scale: A review of innovations in online learning strategies. Computers and Education. https://doi.org/10.1016/j.compedu.2018.05.019

Dhofier, Z. (2011). Tradisi Pesantren, cet. VI, Jakarta: LP3ES.

Dhofier, Z. (2014). Dawr al-Mu'assasat al-Tarbawīyah al-Islāmīyah al-Taqlīdīyah fī Ta'mīm alTa'līm al-Asāsī fī Indūnīsīyā. Studia Islamika. https:// doi.org/10.15408/sdi.v1i2.857

Eggen, P. dan K. (2012). Strategi dan model pembelajaran: Mengajarkan konten dan ketrampilan berfikir. indeks. 
The Development of Learning Strategies in Pesantren Studies on the Transformation of the Teaching System in Pesantren

Fanani, A. (2014). Mengurai kerancuan istilah strategi dan metode pembelajaran. Nadwa. https://doi.org/10.21580/nw.2014.8.2.576

Fuadi, A., \& Suyatno, S. (2020). Integration of nationalistic and religious values in islamic education: study in integrated islamic school. Randwick International of Social Science Journal, 1(3), 555-570. https:// doi.org/10.47175/rissj.v1i3.108

Hamruni. (2009). Strategi dan model-model pembelajaran aktif menyenangkan. fakultas Tarbiyah UIN Sunan Kalijaga.

Hamruni, H. (2016). The challenge and the prospect of pesantren in historical review. Jurnal Pendidikan Islam. https:// doi.org/10.14421/jpi.2016.52.413-429

Hamruni, H., \& Salamah, U. (2017). Pembinaan agama islam di pesantren Muntasirul Ulum Man Yogyakarta Iii. LITERASI (Jurnal Ilmu Pendidikan). https://doi.org/10.21927/literasi.2016.7(2).89-101

Hidayah, B. (2019). Peningkatan kemampuan membaca kitab kuning melalui pembelajaran arab pegon. Jurnal Ilmu Pendidikan.

Idaho Digital Learning. (2014). 6 Models of Blended Learning.

Laland, K. N., \& Rendell, L. (2019). Social learning: Theory. In Encyclopedia of Animal Behavior. https://doi.org/10.1016/B978-0-12-813251-7.00057-2

Lukens-Bull, R. A., \& Dhofier, Z. (2000). The pesantren tradition: A study of the role of the kyai in the maintenance of the traditional ideology of islam in Java. The Journal of Asian Studies.

Malisi, M. A. S. (2012). Pembaruan pendidikan di pesantren; Studi Kasus pada Pesantren Rasyidiyah Khalidiyah Amuntai Kalimantan Selatan. UIN Syarif Hidayatullah Jakarta.

Matiisen, T., Oliver, A., Cohen, T., \& Schulman, J. (2020). Teacher-student curriculum learning. IEEE Transactions on Neural Networks and Learning Systems. https://doi.org/10.1109/TNNLS.2019.2934906

Maunah, B. (2015). Lembaga pendidikan islam di indonesia: Kajian deskripsi-analitik model lembaga pendidilan islam. Empirisma. https://doi.org/10.30762/empirisma.v24i2.23

McCombs, B. L. (2017). Historical review of learning strategies research: Strategies for the Whole Learner - A tribute to claire ellen weinstein and early researchers of this topic. In Frontiers in Education. https:// doi.org/10.3389/feduc.2017.00006

McLeod, S. (2018). B.F. skinner: Operant conditioning. Simply Psychology.

Munadi, M. (2016). Integration of islam and science: Study of two science pesantrens (Trensain) in Jombang and Sragen. 5(December).

Mustakim, M. (2019). School and pesantren: Study of institutional transformation of islamic education in pesantren-based schools (SBP) Ibnu Abbas Klaten Indonesia. https://doi.org/10.2991/iccd19.2019 .90

Nata, A. (2014). Sejarah pendidikan islam. Kencana.

Nisbet, J., \& Shucksmith, J. (2017). Learning strategies. In Learning Strategies. https://doi.org/10.4324/9781315188652

Noeng Muhadjir, S. (2013). Metode penelitian. Journal of chemical information and modeling.

Ritonga, T., Ananda, A., Lanin, D., \& Hasan, H. (2019). Practice to theory of learning: A lesson learned from islamic boarding school in South Tapanuli of Indonesia. Humanities and Social Sciences Reviews. https:/ / doi.org/10.18510/hssr.2019.75169

Riyanto, Y. (2014). Paradigma baru pembelajaran. In Seminar Nasional FMIPA UNDIKSHA IV Tahun 2014.

Royani, A. (2018). Eksistensi pendidikan pesantren dalam arus perubahan. Cendekia: Jurnal Kependidikan Dan Kemasyarakatan. https://doi.org/10.21154/cendekia.v16i2.1242

S.A.P., R. S., Tobroni, Ishomuddin, \& Khozin. (2020). The meaning construction of a scientific approach on teaching islamic education. International Journal of Psychosocial Rehabilitation. https://doi.org/10.37200/IJPR/V24I9/PR290284

Salim, A. (2014). Pembelajaran pendidikan agama islam. Cendekia.

Salimans, T., Ho, J., Chen, X., Sidor, S., \& Sutskever, I. (2017). Evolution strategies as a scalable 
The Development of Learning Strategies in Pesantren Studies on the Transformation of the Teaching System in Pesantren

alternative to reinforcement learning. In arXiv.

Sanjaya, W. (2013). Kurikulum dan pembelajaran : Teori dan praktik pengembangan kurikulum tingkat satuan pendidikan (KTSP). Jakarta :Kencana Prenada Media Group.

Sanjaya, W., Warsita, B., Pembelajaran, T., \& Nata, A. (2013). Rancangan strategi pembelajaran guru PAI DPK SMP Babussalam. Al-Fikra:Jurnal Ilmiah Keislaman,.

Schunk, D. H. (2012). Learning theories: An educational perspective. In Reading.

SHIDDIQ, A. (2017). Tradisi akademik pesantren: Perubahan Sistem Manajemen Dari Tradisional Ke Modern. FIKROTUNA. https://doi.org/10.32806/jf.v4i2.2748

Sholihin, M. (2016). Modernisasi pendidikan pesantren (Studi Kasus di Pesantren Darul Lughah wal Karomah Kraksaan Probolinggo).

Simkova, Z. (2015). Learning styles and strategies. Slavonic Pedagogical Studies Journal. https://doi.org/10.18355/pg.2015.4.1.82-88

Soleh, A., Maya, R., \& Priyatna, M. (2018). Metode halaqah dalam pembelajaran tahfidz alquran di pondok pesantren tahfidz alquran darussunnah parung kabupaten Bogor Tahun 2018. Prosiding Al Hidayah Pendidikan Agama Islam.

Steenbrink, K. (2015). Academic study of indonesian islam a Biographical Account 1970-2014. Al Jami'ah; Journal of Islamic Studies, 53(2), 337-365. https://doi.org/10.14421/ajis.2015.532.337-365

Sugiyono. (2016). Memahami penelitian kualitatif. Bandung: Alfabeta.

Sugiyono. (2017). Metode penelitian kualitatif: Untuk penelitian yang bersifat: Eksploratif, Enterpretitif, dan Konstruktif. In Alfabeta.

Sumantri, M. S. (2015). Strategi pembelajaran: Teori dalam praktik di tingkat pendidikan dasar. Rajawali Press.

Wajdi, F., \& Nur Aulia, R. (2019). Ma'had 'Aly and the challenge of modernizing islamic education in Indonesia. Hayula: Indonesian Journal of Multidisciplinary Islamic Studies. https://doi.org/10.21009/hayula.003.2.04

Yin, R. K. (2012). Case study methods. In Handbook of Complementary Methods in Education Research. https://doi.org/10.4324/9780203874769-11

Zaini, H. (2016). Strategi pembelajaran aktif. Seminar Lokakarya Nasional Pendidikan Biologi FKIP UNS.

\footnotetext{
${ }^{*}$ Muh. Mustakim (Corresponding Author)

Department of Islamic Education, Faculty of Islamic Religion,

Alma Ata University, Yogyakarta

Jl. Brawijaya 99, Yogyakarta, 55183, Indonesia

Email: muh.mustakim@almaata.ac.id
} 